\title{
On the taxonomy of Trechaleidae (Araneae: Lycosoidea) from Colombia and Peru
}

\author{
Estevam Luís Cruz da Silva \& Arno Antonio Lise
}

Laboratório de Aracnologia, Museu de Ciências e Tecnologia, Pontifícia Universidade Católica do Rio Grande do Sul. Avenida Ipiranga 6681, prédio 40, sala 125, $90619-900$ Porto Alegre, Rio Grande do Sul, Brasil.

E-mail: estevamsilva@gmail.com; lisearno@pucrs.br

\begin{abstract}
A new species of Enna O. Pickard-Cambridge, 1897 from Cusco, Peru and two new species of Caricelea Silva \& Lise, 2007 based in males collected in Cusco, Peru are described. Enna echarate sp. nov. can be distinguished from other species by the two lateral excavations on the epigynal middle field. Caricelea apurimac sp. nov. an be distinguished from the other members of the genus, by the larger lamellar projection (LP) on the median apophysis that covers most of the guide. Caricelea camisea sp. nov. can be distinguished from other species of the genus, by the smaller lamellar projection and the smaller and acute ental division of the retrolateral apophysis. The males of Hesydrus caripito Carico, 2005 and Syntrechalea reimoseri (Caporiacco, 1947) are described and illustrated for the first time. Trechalea numida Mello-Leitão, 1943 and Trechalea limai Mello-Leitão, 1941 are transferred to Thaumasia Perty, 1833 (Pisauridae) and Paratrechalea Carico, 2005 (Trechaleidae) as species inquirenda and nomen dubium, respectively. New records of Hesydrus aurantius (Mello-Leitão, 1942), Hesydrus caripito Carico, 2005, Enna maya Silva, Lise \& Carico, 2008 and Syntrechalea reimoseri (Caporiacco, 1947) from Colombia and Peru are presented.
\end{abstract}

KEY WORDS. distribution; new species; Neotropical region, taxonomy.

Trechaleidae spiders can be can be found near or in the vegetation of the margins of rocky streams (CARICO 1993). The material gathered during the past five years from South America presented a high richness of species, especially in some regions of Peru and Colombia.

In this work, we describe and illustrate a new species of Enna from Cusco, Peru and two new species of Caricelea Silva \& Lise, 2007 also from Cusco, Peru. The males of Hesydrus caripito Carico, 2005 and Syntrechalea reimoseri (Caporiacco, 1947) are described and illustrated for the first time. New records of the distribution of Hesydrus aurantius (Mello-Leitão, 1942) and Enna maya Silva, Lise \& Carico, 2008 in Peru and Colombia are presented.

\section{MATERIAL AND METHODS}

The material examined is deposited in American Museum of Natural History, New York, USA (AMNH, N. Platnick), Instituto de Ciencias Naturales de la Universidad Nacional de Colombia (ICN, E. Florez), Museo de Historia Natural de la Universidad Nacional Mayor de San Marcos, Lima, Peru (MUSM, D. Silva-Dávila) and Museu Nacional da Universidade Federal do Rio de Janeiro, Brazil (MNRJ, A.B. Kury). The nomenclature of the male palpal structures follows Carico $(1993,2008)$ and Silva et al. (2008). To study the excised epigyna, the soft tissue was removed by a combination of dissection with a small surgical blade and immersion in the enzyme tripsine for 48 hours at $25^{\circ} \mathrm{C}$. All the measurements are in millimeters. The abbreviations related to eyes measurements, including diameter, interdistances and median ocular quadrangle are those routinely used in spider descriptions.

\section{TAXONOMY}

Paratrechalea limai (Mello-Leitão, 1941), comb. nov. Trechalea limai Mello-Leitão, 1941: 245, figs 1 and 2 (Male and female syntypes from Iguape, São Paulo, Brazil, O. Leonardos leg., deposited in the MNRJ 41857, not examined, type assumed to be lost). Mello-Leitão, 1941: 253. Carico, 1993: 237. Carico, 2005: 798. Platnick, 2008.

Remarks. The name is transferred to Paratrechalea (Trechaleidae) as a nomen dubium, based on the original descriptions, measurements, coloration pattern and drawings that present enough diagnostic characters to include this species in the genus, like the "scape-like" projection of the female epigynum typical of species of Paratrechalea and the type locality is in the range of distribution of the genus. Since the type is assumed to be missing from the collection of MNRJ, based on the original drawings, we can not determine the species. 


\section{Thaumasia numida (Mello-Leitão, 1943), comb. nov.}

Trechalea numida Mello-Leitão, 1943: 3 (Immature female holotype from Caruaru, Pernambuco, Brazil, R. von Ihering leg., deposited in the MNRJ 41857, examined). Roewer, 1954: 143. Carico, 1993: 237 (nomen dubium). Platnick, 2008.

Remarks. Trechalea numida is transferred to Thaumasia (Pisauridae) as species inquirenda, based on the typical dorsal pattern in most species of the latter genus, i.e., wide median dark area with lateral white bands.

\section{Caricelea apurimac sp. nov.} Figs 1-4

Type. Male holotype from Apurimac river, Cusco, Peru, 28.VII.1997, J. Duarez \& S. Cordova leg., deposited in MUSM 500067.

Diagnosis. This species can be distinguished from the other members of the genus, by the larger lamellar projection (LP) on the median apophysis that covers most of the guide (Fig. 2).

Description. Holotype male. Total length 7.63. Carapace dark brown, darker laterally, brownish striate lines at anterior area, 3.56 long, 2.98 wide. Clypeus dark brown, 0.34 high. Anterior eye row slightly straight, 0.90 wide; posterior 1.66 wide. Eye diameters, interdistances, and median ocular quadrangle: AME 0.16, ALE 0.12, PME 0.26, PLE 0.14; AME-AME 0.12, AMEALE 0.10, PME-PME 0.42, PME-PLE 0.30, OQA 0.46, OQP 0.90, $\mathrm{OQH}$ 0.60. Chelicerae red-brownish, bristly, with lateral carina; promargin and retromargin of fang furrow with three teeth equidistant and equal in size. Sternum yellowish, scattered setae; 1.41 long, 1.66 wide. Labium dark brown, bristly, 0.49 long, 0.58 wide. Legs brownish with light brown annuli on femora, relative length: I-IV-II-III, I - femur 4.73/tibia-patella 7.05/metatarsus 5.22/tarsus 2.07/total 19.07; II - 4.98/6.22/4.56/1.82/17.58; III - 3.56/3.31/3.40/1.49/11.76; IV - 4.39/5.39/5.81/2.07/17.66. Ventral pairs of macrosetae on tibiae: I-5; II-4; III-3; IV-3. Abdomen, 3.32 long, grayish, bristly; brownish laterally. Venter yellowish, with scattered setae. Ventral division of median apophysis with large lamellar projection (Fig. 2); guide acute and retrolaterally curved (Fig. 2). Retrolateral tibial apophysis (RTA) prominent, ectal division rounded at apex (Figs 3 and 4); ental division triangular and pointed at apex (Figs 3 and 4).

Female. Unknown.

Distribution. Known only from the type locality (Fig. 1). Etymology. The specific name is a noun in apposition and refers to the type locality.

\section{Caricelea camisea sp. nov.}

Figs 1, 5-7

Type. Male holotype from Camisea river, Cashiriari, Cusco, Peru, VI.1997, J. Duarez \& S. Cordova leg., deposited in MUSM 500065.

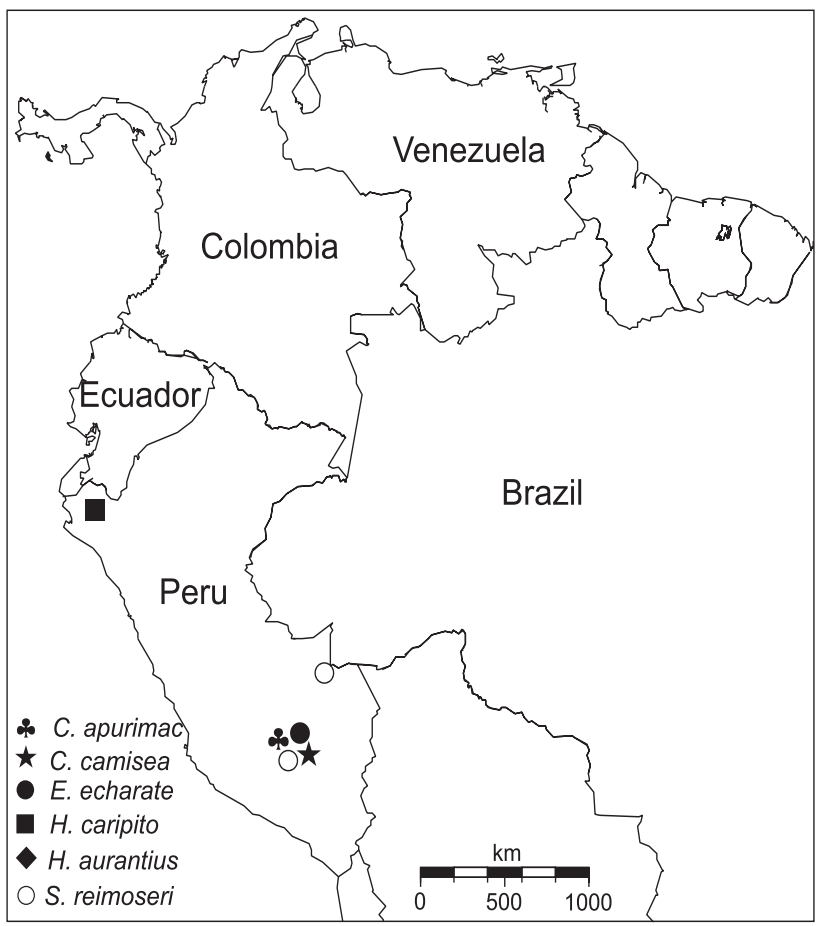

Figure 1. Distributions of C. apurimac sp. nov., C. camisea sp. nov., Enna echarate sp. nov., $H$. caripito, $H$. aurantius and $S$. reimoseri in Peru and Colombia.

Diagnosis. The male of $C$. camisea sp. nov. resembles the ones of C. wayrapata (see SiLva \& LiSe 2007, figs 4-6) by the general shape of the median apophysis, but can be distinguished by the smaller lamellar projection and the smaller and acute ental division of the retrolateral apophysis (Fig. 5).

Description. Male (Holotype). Total length 5.06. Carapace light brown, darker laterally, with an "u" shaped spot at anterior area, 2.57 long, 2.24 wide. Clypeus dark brown, 0.20 high. Anterior eye row slightly straight, 0.70 wide; posterior 1.30 wide. Eye diameters, interdistances, and median ocular quadrangle: AME 0.14, ALE 0.10, PME 0.24, PLE 0.14; AMEAME 0.07, AME-ALE 0.06, PME-PME 0.26, PME-PLE 0.22, OQA 0.38, OQP 0.70, OQH 0.51. Chelicerae red-brownish, bristly, with lateral carina; promargin and retromargin of fang furrow with three teeth equidistant and equal in size. Sternum yellowish, with scattered setae; 1.16 long, 1.32 wide. Labium dark brown, darker laterally, 0.40 long, 0.41 wide. Legs brownish with light brown annuli on femora, relative length: I-IVII-III, I - femur 3.92/tibia-patella 4.73/metatarsus 3.48/tarsus 1.49/total 13.02; II - 3.31/3.98/3.23/1.24/11.76; III - 2.57/ 2.98/2.49/0.85/8.89; IV - 3.15/4.15/3.98/1.32/12.60. Ventral pairs of macrosetae on tibiae: I-5; II-4; III-3; IV-3. Abdomen, 2.65 long, grayish, with scattered small light dots and three small horizontal bands. Venter yellowish, with scattered se- 

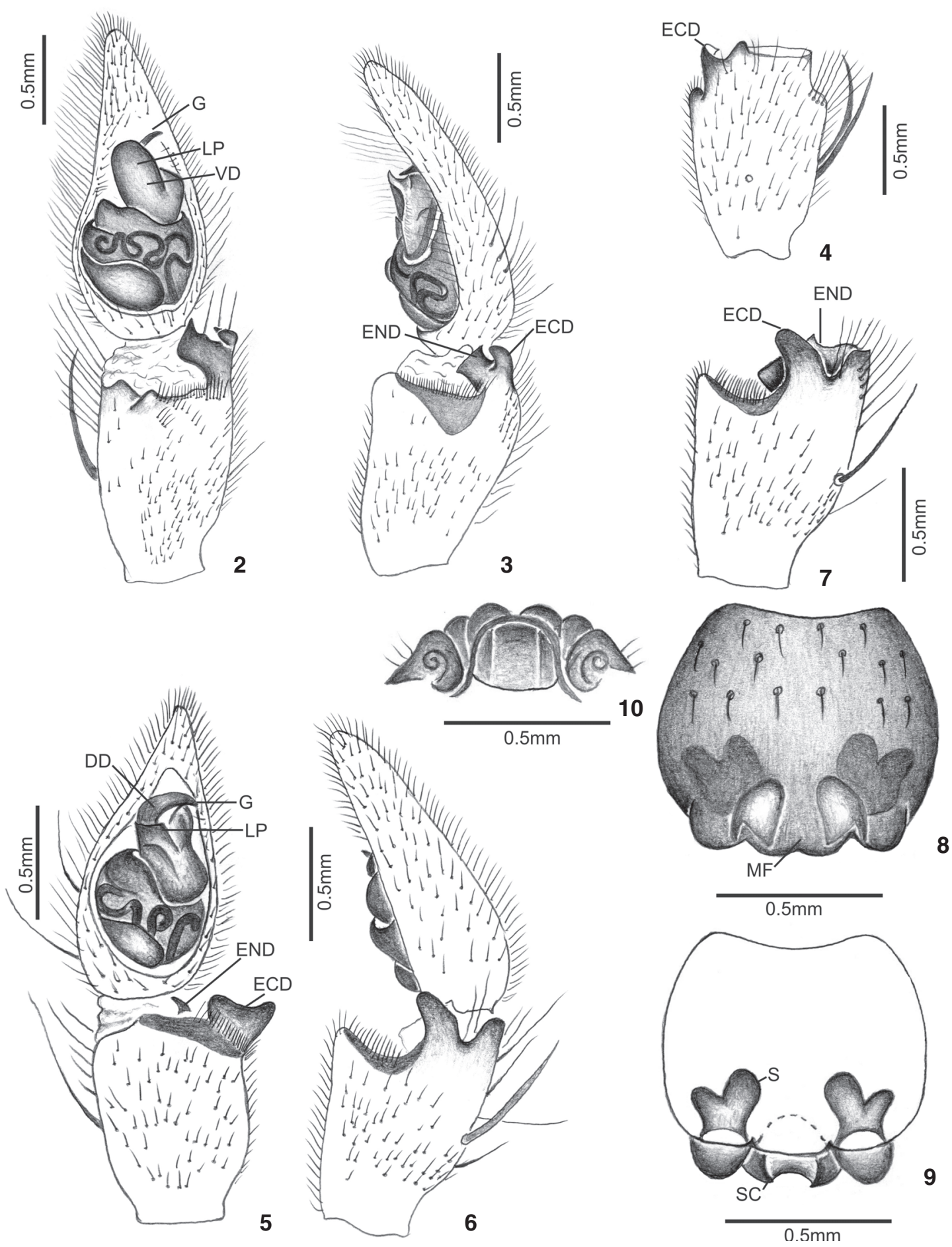

Figures 2-10. Carilea apurimac sp. nov., male palpus: (2) ventral view. (3) retrolateral view. (4) dorsal view (detail of retrolateral apophysis). (5-7) C. camisea sp. nov., male palpus: (5) ventral view; (6) retrolateral view; (7) detail of retrolateral tibial apophysis, dorsal view; (8-10) E. echarate sp. nov., female epigynum: (8) ventral view; (9) dorsal view; (10) posterior view. (ECD) Ectal division of RTA, (END) ental division of RTA, (G) guide, (LP) lamellar projection, (MF) middle field of epigynum, (RTA) retrolateral tibial apophysis, (S) spermatheca, (SC) scape, (VD) ventral division of median apophysis. 
tae. Ventral division of median apophysis with small lamellar projection (Fig. 5); guide pointed and curved (Fig. 5). Retrolateral tibial apophysis (RTA) prominent, ectal division rounded at apex (Figs 6 and 7); ental division small and triangular (Fig. 7).

Female. Unknown.

Distribution. Known only from the type locality (Fig. 1).

Etymology. The specific name is a noun in apposition and refers to the type locality.

\section{Enna echarate sp. nov.}

Figs 1, 8-10

Type. Female holotype from Puente Chaguares, Echarate, Cusco, Peru, 09.VIII.1989, R. Tejada leg, deposited in MUSM 500054 .

Diagnosis. The female of $E$. echarate sp. nov. is similar to E. rothi (see Silva et al. 2008, figs $46-48$ ) by the general shape of the epigynal middle field, but can be distinguished by the two lateral excavations on that region (Fig. 8).

Description. Female (Holotype). Total length 8.54. Carapace 3.48 long, 3.15 wide, light brown, darker laterally. Clypeus brownish, 0.26 high. Anterior eye row slightly straight, 0.90 wide; posterior 1.66 wide. Eye diameters, interdistances, and median ocular quadrangle: AME 0.18, ALE 0.12, PME 0.24, PLE 0.20; AME-AME 0.12, AME-ALE 0.10, PME-PME 0.43, PME-PLE 0.28 , OQA 0.48 , OQP 0.88 , OQH 0.53. Chelicerae red-brownish, bristly, without lateral carina; promargin and retromargin of fang furrow with three teeth equidistant and equal in size. Sternum yellowish, with scattered setae; 1.49 long, 1.57 wide. Labium light brown, darker anteriorly, 0.74 long, 0.58 wide. Legs brownish with light brown annuli on femora, relative length: I-II-IV-III, I - femur 4.15/tibia-patella 5.39/metatarsus 3.98/tarsus 1.49/total 15.01; II - 4.16/5.31/3.56/1.57/14.60; III -2.32/2.73/2.07/0.83/7.95; IV - 2.47/3.15/3.01/0.91/9.54. Ventral pairs of macrosetae on tibiae: I-4; II-3; III-3; IV-3. Abdomen, 4.98 long, grayish, bristly, with small light dots. Venter yellowish, with scattered setae. Middle field of epigynum with two small excavations (Fig. 8), scape slightly projected (Figs 9 and 10); spermathecae rounded at apex (Fig. 9).

Male. Unknown.

Distribution. Known only from the type locality (Fig. 1).

Etymology. The specific name is a noun in apposition and refers to the type locality.

\section{Enna maya Silva, Lise \& Carico, 2008}

Enna maya Silva, Lise \& Carico, 2008: 85, figs 37-39 (Female holotype from Copan, Honduras, 08.III.1939 deposited in AMNH, examined).

Distribution. Costa Rica, Honduras, Peru.

Additional record. Peru, Madre de Dios, $15 \mathrm{~km}$ east from Puerto Maldonado ( $\left.12^{\circ} 33^{\prime} \mathrm{S}, 6^{\circ} 03^{\prime} \mathrm{W}, 200 \mathrm{~m}\right), 1$ female, 19.VIII.1989, D. Silva leg. (MUSM 0500055).

\section{Hesydrus caripito Carico, 2005}

Figs $1,11,12$

Hesydrus caripito Carico, 2005: 793, figs 16 and 17 (Female holotype from Caripito, Monagas, Venezuela, $10^{\circ} 80^{\prime} 79^{\prime \prime} \mathrm{N}$, 6380'69"W, 17.III.1942, New York Zoological Society 1942 Venezuela Expedition leg, deposited in AMNH, not examined). Platnick, 2008.

Diagnosis. The males of $H$. caripito is similar to the ones of H. canar (see CARICo 2005, figs 12 and 13) by the bifurcated apex of the ectal division of the retrolateral tibial apophysis (Fig. 12), but can be distinguished by the absence of a pointed spur on the apex of the guide of the median apophysis (Fig. 11).

Description. Male (MUSM 500070). Total length 12.36. Carapace 6.78 long, 6.65 wide, brownish, darker on cephalic area; bristly laterally. Clypeus yellowish, 0.31 high. Anterior eye row slightly straight, 0.99 wide; posterior 2.66 wide. Eye diameters, interdistances, and median ocular quadrangle: AME 0.25, ALE 0.15, PME 0.35, PLE 0.31; AME-AME 0.21, AME-ALE 0.09, PME-PME 0.49, PME-PLE 0.62, OQA 0.77, OQP 1.24, OQH 1.02. Chelicerae red-brownish, with lateral carina; promargin and retromargin of fang furrow with three teeth equidistant and equal in size. Sternum yellowish, with scattered setae; 3.80 long, 3.19 wide. Labium light brown, darker posteriorly, 1.06 long, 1.19 wide. Legs light brown, with light brown annuli on femora, relative length: IV-II-I-III, I - femur 7.98/tibia-patella 10.64/metatarsus 8.24/tarsus 4.25/total 31.11; II - 10.10/12.91/8.64/4.65/ 36.30; III - 8.11/9.97/7.83/4.52/30.43; IV - 8.92/11.70/11.98/ $5.98 / 38.58$. Ventral pairs of macrosetae on tibiae: I-4; II-4; III-3; IV-3. Abdomen 5.98 long, grayish, bristly, with two small paramedian light brown bands. Venter yellowish, scattered setae. Ventral division of median apophysis truncated medially; dorsal division ending in acute guide (Fig. 11). Retrolateral tibial apophysis prominent, ectal division bilobed (Fig. 12).

Additional records. Colombia, Valle: Restrepo, 1 female, no date, Equipe Universidad Nacional leg. (ICN 685); Santander: Charalá, Virolín, 1 female, III.1981, I. de Arévalo leg. (ICN 688); Boyaca: Quebrada la Cristalina, 1 male, 1 female, 06.III.2000, M. Rocha leg. (ICN 1037); Cundinamarca: Caquezá, rio Blancorio Negro, 1 female, 04.IV.2002, A. Ruiz leg. (ICN 1739); Tolima: Ibague, 1 female, 24.II.2002, H. Pullido leg. (ICN 1740). PERU, Piura: Mangas river, 1 male, 2 females, 1 juvenile, 06.X.1955, F. Blancas leg. (MUSM 500070).

Distribution. Colombia, Peru, Venezuela (Fig. 1).

Natural history. Unknown.

\section{Hesydrus aurantius (Mello-Leitão, 1942)}

Trechalea aurantia Mello-Leitão, 1942: 430, figs 3-4 (male and two female syntypes from La Merced, Junín, Peru, J. Soukup leg., deposited in MNRJ 2310, examined, male lectotype and female paralectotype designated by Silva, 2006). Platnick, 2008.

Hesydrus aurantius: Silva, 2006: 50. Platnick, 2008.

Distribution. Colombia, Peru, Bolivia. 

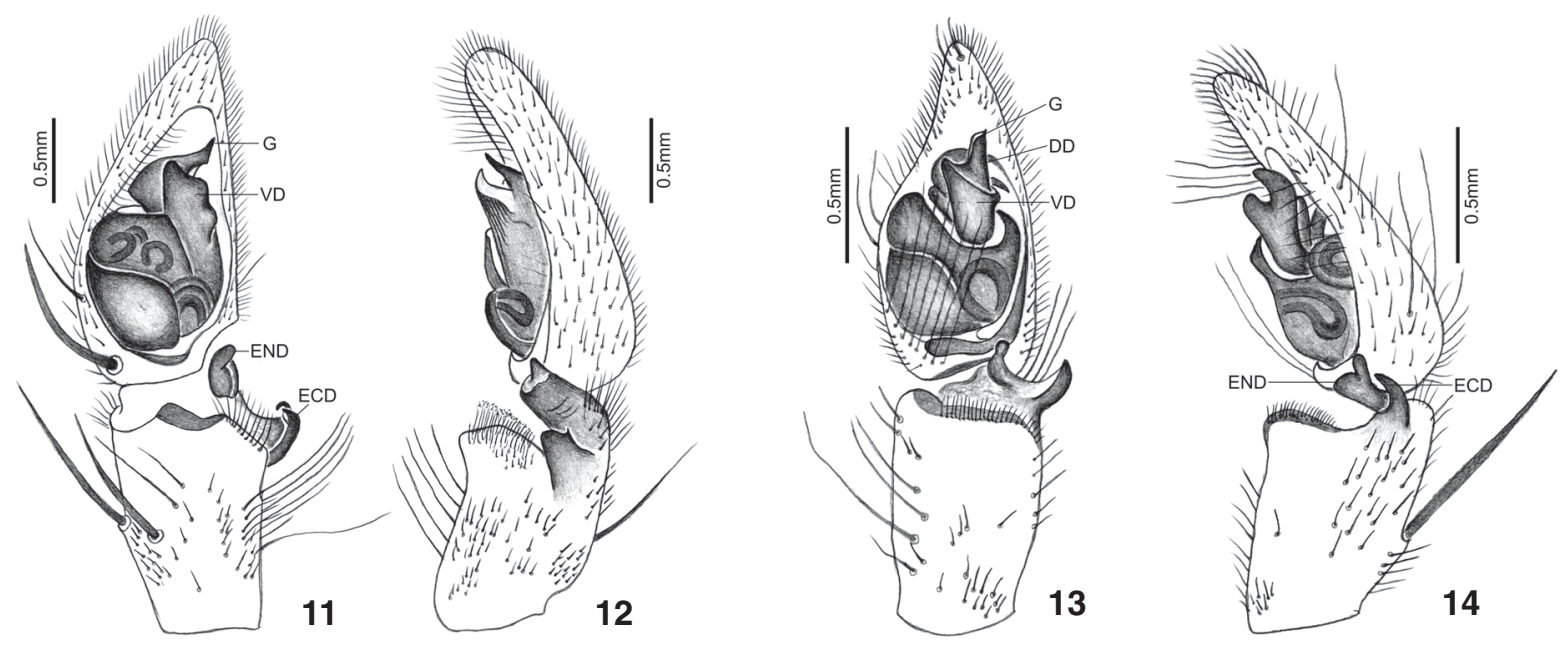

Figures 11-12. Hesydrus caripito, male palpus: (11) ventral view; (12) retrolateral view; (13-14) S. reimoseri, male palpus: (13) ventral view; (14) retrolateral view. (DD) Dorsal division of median apophysis, (ECD) ectal division of RTA, (END) ental division of RTA, (RTA) retrolateral tibial apophysis, (G) guide, (VD) ventral division of median apophysis.

Additional records. Colombia, Boyaca: Ins. Pto. Quebrada la Cristalina, 1 male, 1 female, 06.III.2000, M. Rocha leg. (ICN 1037), 1 female, 03.III.2002, H. Gasca leg. (ICN 1040). Peru, Ucayali: Pucallpa, Puente Huacamayo, 2 males, 1 female, 28.VIII.1986, D. Silva leg. (MUSM 0500068); Huanuco: Tingo Maria, Cueva de lãs Pavas ( $9^{\circ} 24^{\prime}$ S, 755' $\mathrm{W}, 800$ m), 1 female, 24-30.X.2004, W. Paredes leg. (MUSM 0500073), Pucallpa, 5km from la Cumbre $\left(9^{\circ} 11^{\prime} \mathrm{S}, 75^{\circ} 48^{\prime} \mathrm{W}, 677 \mathrm{~m}\right), 2$ males, 02.IX.2007, W. Paredes leg. (MUSM 0500074); Amazonas: Cordillera del Condor, Alto Rio Comaina, Quebrada Ponce, 3 males, 2 females, 02.XI.1987, D. Silva leg. (MUSM 0500072); Madre de Dios: Zona Preservada Pakitza, Quebrada Pachija (11 ${ }^{\circ} 56^{\prime} \mathrm{S}, 71^{\circ} 17^{\prime} \mathrm{W}, 356$ m), 2 males, 2 females, 17.VII.1992, D. Silva leg. (MUSM 0500029); Cusco: Líne Gaseoducto Peru LNG (12¹9'S, $\left.73^{\circ} 02^{\prime} \mathrm{W}\right)$, 2 females, 19-22.IV.2007, W. Paredes leg. (MUSM 0500069).

\section{Syntrechalea reimoseri (Caporiacco, 1947)}

Figs $1,13,14$

Trechalea reimoseri Caporiacco, 1947: 22; Caporiacco, 1948: 634;

Roewer, 1954: 143; Platnick, 2008.

Syntrechalea reimoseri: Carico, 1993: 237; Carico, 2008: 121.

Diagnosis. The males of S. reimoseri (Caporiacco, 1947) resembles the ones of $S$. syntrechaloides (Mello-Leitão, 1941) (see CARICO 2008, figs 20 and 21) by the shape of the ventral division of the median apophysis of the male palpus, but can be distinguished by the long, slender and acute guide and the acute ectal division of the retrolateral tibial apophysis (Figs 13 and 14).

Description. Male (MUSM 500044). Total length 7.48. Carapace 2.88 long, 2.63 wide, yellowish, darker on cephalic area. Clypeus yellowish, 0.22 high. Anterior eye row slightly straight, 0.78 wide; posterior 1.60 wide. Eye diameters, interdistances, and median ocular quadrangle: AME 0.14, ALE 0.10, PME 0.30, PLE 0.14; AME-AME 0.12, AME-ALE 0.08, PMEPME 0.30, PME-PLE 0.24, OQA 0.44, OQP 0.88, OQH 0.65. Chelicerae yellowish, without lateral carina; promargin and retromargin of fang furrow with three teeth equidistant and equal in size. Sternum yellowish, with scattered setae; 1.55 long, 1.45 wide. Labium yellowish, darker laterally, 0.18 long, 0.43 wide. Legs yellowish, I - missing; II - missing; III - femur 5.58/ tibia-patella 6.11/metatarsus 5.32/tarsus 3.45/total 20.46; IV 7.98/9.57/9.98/5.71/33.24. Ventral pairs of macrosetae on tibiae: III-7; IV-8. Abdomen, 4.53 long, heart shaped anteriorly, grayish, with scattered setae; dorsum yellowish. Venter yellowish, with scattered setae. Ventral division of median apophysis acute distally (Fig. 13); guide pointed and apically curved (Fig. 13). Retrolateral tibial apophysis prominent, ectal division acute at apex (Fig. 14); ental division lobed (Fig. 14).

Distribution. Ecuador, Peru, Guyana, Brazil (Fig. 1).

Material examined. Peru, Cusco: Kugapocori-Nahua (76 $\left.88^{\prime} \mathrm{S}, 86^{\circ} 90^{\prime} \mathrm{W}\right), 422 \mathrm{~m}, 1$ male, 1 female, 28.VII.2007, C. Torres leg. (MUSM 0500044); Madre de Dios: $15 \mathrm{~km}$ east from Puerto Maldonado (12 $\left.33^{\prime} \mathrm{S}, 6^{\circ} 03^{\prime} \mathrm{W}, 200 \mathrm{~m}\right), 1$ female, 3 juveniles, 01-08.VII.1989, D. Silva leg. (MUSM 0500053).

\section{ACKNOWLEDGMENTS}

We wish to thank Diana Silva-Dávila (MUSM) and Eduardo Florez (ICN) for the loan of the material and James E. Carico (Lynchburg College) for comments on the manuscript. This study was supported by Conselho Nacional de Desenvolvimento Científico e Tecnológico (140282/2008-4 for ELCS). 


\section{LITERATURE CITED}

Caporiacco, L. Di. 1947. Diagnosi preliminari de specie nuove di aracnidi della Guiana Brittanica raccolte dai professori Beccari e Romiti. Monitore Zoologico Italiano 56: 20-34.

CAPORIACCO, L. DI. 1948. Arachnida of British Guiana collected in 1931 and 1936 by Professors Beccari and Romiti. Proceedings of the Zoological Society of London 118: 607747.

Carico, J.E. 1993. Revision of the genus Trechalea Thorell (Araneae, Trechaleidae) with a review of the taxonomy of the Trechaleidae and Pisauridae of the Western Hemisphere. Journal of Arachnology 21 (3): 226-257.

CARICO, J.E. 2005. Revision of the spider genus Hesydrus (Araneae, Lycosoidea, Trechaleidae). Journal of Arachnology 33 (3): 785-796.

Carico, J.E. 2008. Revision of the Neotropical arboreal spider genus Syntrechalea (Araneae, Lycosoidea, Trechaleidae). Journal of Arachnology 36 (1): 118-130.

Mello-Leitão, C. 1941. Aranhas do Paraná. Arquivos do Insti- tuto Biológico de São Paulo 11: 235-257.

Mello-Leitão, C. 1942. Cinco aranhas novas do Peru. Revista Brasileira de Biologia 2: 429-434.

Mello-Leitão, C. F. DE. 1943. Alguns pisauridas e tomisidas do Brasil. Revista Chilena de Historia Narural 45: 164-172.

Platnick, N.I. 2008. The World Spider Catalog version 9.0. New York, American Museum of Natural History, available on line at: http://research.amnh.org/entomology/spiders/ catalog/html [Access: 10.XI.2008].

Roewer, C.F. 1954. Katalog der Araneae. Bruxelles, Institut Royal des Sciences Naturelles de Belgique, vol. 2a, 923p.

SilvA, E.L.C. 2006. Redescrição de Hesydrus aurantius comb. nov. (Araneae, Lycosoidea, Trechaleidae). Biociências 14 (1): 49 51.

Silva, E.L.C. \& A.A. Lise. 2007. On a new genus of Trechaleidae (Araneae, Lycosoidea) from Peru. Revista Ibérica de Aracnología 14: 25-29.

SilvA, E.L.C.; A.A. Lise \& J.E. CARICO. 2008. Revision of the Neotropical spider genus Enna (Araneae, Lycosoidea, Trechaleidae). Journal of Arachnology 36 (1): 76-110.

Submitted: 12.IX.2008; Accepted: 11.VI.2009.

Editorial responsability: Antônio D. Brescovit 